Jobmark: Journal of Branding and Marketing Communication

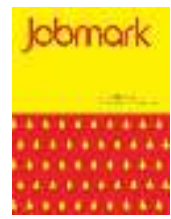

Vol. 2(1) pp. 9-23, (2020) DOI:I0.36782/jobmark.v2il.55

\section{How the Digital Endorsement Campaign Affects Student's Attitude towards a Cinema Theater Brand: The Case of \#JajanAsyikXXI on Instagram}

\author{
Qisti Qasthari' and Pudjiastuti Wahyuni2 ${ }^{*}$
}

\begin{abstract}
The rapid number of social media users and changes in consumer behavior today requires marketers to adapt quickly. The use of celebrity endorser "Titan Tyra" in the \#JajanAsikDiXXI campaign on Instagram is one of XXI's digital promotional activities. This study measures the effect of celebrity endorser characteristics "Titan Tyra" in the \#JajanAsikdiXXI campaign on the attitudes of Communication Science students at Bakrie University toward the XXI brand. This research uses a quantitative approach with an explanatory case study method. The data was collected using questionnaires, observation, tracing professional documents, and digital documentation. The distribution of questionnaires was carried out to 86 active students of Communication Science at Bakrie University using cluster random sampling where the clusters used were classes from each course that took place in the even semester of $2019 / 2020$. The results showed that all the characteristics of celebrity endorsers attached to Titan Tyra had a significant and simultaneous influence on the attitudes of active students of Communication Science at Bakrie University towards the XXI brand. This research is worthwhile to provide insight to marketers about promotional activities using celebrity endorsers to increase positive brand attitudes.
\end{abstract}

Keywords

Brand attitude, celebrity endorser, social media, cinema brand, XXI

To cite this article ( $7^{\text {th }}$ APA style):

Qasthari, Q. \& Wahyuni, P. (2020). How the Digital Endorsement Campaign Affects Student's Attitude towards a Cinema Theater Brand: The Case of \#lajanAsyikXXI on Instagram. Jobmark: Journal of Branding and Marketing Communication 2(I), 9-23. https://doi.org/I0.36782/jobmark.v2il.55

\section{INTRODUCTION}

The rapid technological progress has made many changes in all aspects of human life. Technological developments that occur are directly proportional to the advancement of the

\footnotetext{
' Creative Strategist, Hiip Indonesia, Cyber2 Tower $28^{\text {th }}$, Jl. HR Rasuna Said, Kuningan, Jakarta, ndonesia

2 Department of Communication Science, Universitas Indonesia, Jl. Margonda Raya, Depok, Indonesia
}

*Corresponding author: yuniiqbal@yahoo.com internet. These two things have changed a lot in human life, one of which is consumer behavior.

Changes in consumer behavior today can be seen from the way consumers receive and obtain information. Today's consumers are no longer passive and take information for granted. They tend to selectively and actively seek information about things that interest them.

Along with advances in technology and the internet, marketing communication activities also develop according to circumstances. The ease of access and the complete range of information available on the 
internet has made the internet a new medium used by the public in seeking information. People also use the internet as a tool for socializing.

Not only the general public, companies, or brands also use the Internet as a tool in marketing their products through digital marketing activities. According to Kingsnorth (2016) digital marketing is a derivative of marketing communication activities. Purwana et al. (2017) define digital marketing as the digital media promotional activities carried out with the help of the Internet so that all the process occurs online. According to Nursatyo (2018) digital marketing consists of interactive and integrated marketing communications that make it easier for producers, intermediaries and potential consumers to interact. With digital marketing communications, marketers can reach target markets and build relationships with consumers and potential consumers around the world without being limited by distance and time. Nowadays digital marketing communications and internet use have become commonplace by marketers.

The ability to see gaps and observe ongoing trends can help marketers to sell products and create consumer needs. One of the strategies used by marketers is to innovate in the promotion. Since the increasing use of the internet and social media, marketers have started promoting their products through people who have a large number of followers on various social media platforms.

$\mathrm{XXI}$, a known business brand engaged in entertainment, is now presenting an innovation, the boba drinks that are favored by the people of Indonesia, especially teens and children. One of the considerations made by $X X I$ is to see and take advantage of the momentum of the upward trend of boba. Quoted from the article HealthLiputan6.com, the results Google Trends data reports in 2019 showed 11.5 times increase in a search for "boba" in the Google search field. In the same article, it was also stated that Google Year in Search 2019 saw an increase in searches with the keyword 'boba' on Youtube by 7.3 times (Harsono, 2019).

On December 22, 2019, XXI officially announced its new product, namely brown sugar boba via Instagram @ cinema.2I (Cinema2I, 20I9). In this post, XXI said that now consumers can buy the latest trending drinks and can bring them into the studio to be friends watching their favorite movies. The presence of brown sugar boba is a form of XXI's efforts to increase consumer loyalty and become a brand that can provide consumer needs in one place. Adding a menu according to the wishes and preferences of consumers is also an effort to be able to continue to maintain a positive attitude towards the $X X I$ brand.

$X X I$ Café is a feature branding strategy carried out by the XXI brand. XXI Café was created as a complementary facility based on the behavior of consumers who like watching movies while consuming snacks. The XXI Café service is a part and added value of the services offered by the XXI brand so that consumers can comfortably watch movies and pamper their stomachs without having to go out again to buy snacks.

To make quickly spread information about Boba XXI, the XXI promotion by cooperating with celebrity endorsers on Instagram. This Instagram campaign also includes the hashtag \#JajanAsikDiXXI have a big theme and to make it easier for the audience to find out more. One of the messages that XXI wants to convey through the \#jajanAsikDiXXI campaign is "watching on $X X I$ is even more fun because you can drink your favorite beverage, boba! \#AntiSelundupSelundupClub."

From this message, it can be seen that this campaign aims to form a positive attitude towards the XXI brand itself because it can fulfill consumer desires in one place. This statement was obtained from a brief given by XXI to hiip Indonesia (XXI, 2020).

Based on the results of the search for insights carried out by the authors through social media, the authors found interesting 
findings regarding the attitude of the XXI brand. One of them is from a tweet written by the twitter account @farisandani. In his tweet, Faris wrote:

Masuk ke XXI nggak boleh bawa makanan dari luar. Kalo gitu varian cemilannya jangan itu-itu aja. Ajakin Potato Corner, D'Crepes, Singapore Ice Cream, Chatime, Koi gabung di etalase F\&B-nya XXI. Terdengar egois. Tapi biarin lah

[Entering $\mathrm{XXI}$, you are not allowed to bring food from outside. If so, the variety of snacks provided, don't just be like that. Invite Potato Corner, D'Crepes, Singapore Ice Cream, Chatime, Koi to join the XXI F\&B storefront. Sounds selfish. But let it be!] (Andani, 2019).

The tweet received around 1,200 retweets, which means that 1,200 people have agreed to this statement. This figure can be an indicator of an unfavorable attitude or assessment of the menu variations sold at $X X I$ so that it also has an effect on consumer assessment of the XXI brand as a whole.

From the tweets, it can be seen that XXI's policy on not being able to bring in outside food has not been accompanied by the provision of facilities that can meet consumer wants and preferences. According to Cravens (20I3), personal experience, interaction with other buyers, exposure to marketing activities can be the origin of how consumers behave.

This newly launched boba drink is an answer to the dissatisfaction that is expressed in the form of an attitude towards the brand XXI. Therefore, the $X X I$ party also uses a marketing strategy by collaborating with celebrity endorsers to get positive reviews about the product.

By launching a boba menu that is supported by an endorser who has the nickname Boba Queen, it is hoped that it can create a positive perception and attitude towards the XXI brand. The use of Boba Queen was also chosen to create a quick association about the product being promoted.
Marketers use celebrity endorsements to help better retain information on consumers' minds and helps them to recall the brands (Pughazhendi \& Ravindran, 20I2). Totoatmojo (20I3) said that promotional activities by cooperating with celebrity endorsers as people who carry out promotions on Instagram can provide information with a more personal approach and influence perceptions of the brand image towards products and brands.

Quoted from Ryan (20I5), consumers in the digital realm demand a more personal relationship. From that statement, celebrity endorser be a good option for marketers now days. Promotional activities through celebrity endorsers on social media are also considered quite effective because they can increase share and gain public trust.

This information processing and perception will also influence how consumers behave. The information \& recommendations provided by celebrity endorsers on Instagram also help marketers to target the target market they want because each celebrity endorser has their niche.

The use of celebrity endorsers can influence attitudes which are also supported by previous research entitled "The Influence of Influencer Credibility on Attitudes in Brands (Studies on Students of the Faculty of Communication and Business, Telkom University)" written by Sugiharto and Ramadhana (2018). The results of the research in this journal show that influencers' credibility can significantly influence brand-consumer attitudes.

According to Kotler \& Gary (20I2), brand attitude is the attitude shown by consumers which are obtained from the results of evaluating a brand. Attitude toward brands is also a form of consumer expression in assessing the positive or negative of a brand. Do they like or dislike the products of the brand? Consumer attitudes are an important element that influences the success or failure of the marketing strategy undertaken (Lee \& Johnson, 20II). The 
attitude toward brand describes how consumers act in a real way like making choices about a brand.

The concept of attitude toward brands used by the authors comes from the attitude triangle theory consisting of cognitive, affective, and conative. Where what is seen and measured is the attitude towards the sign, and the sign referred to in this study is a brand. According to Wijaya (20I3), a brand is a trace that is left in the minds and hearts of consumers which creates certain meanings and feelings.

To explore and examine the problems in this study, the authors use several theories, specifically: digital marketing communication theory, celebrity endorser, elaboration likelihood model, and brand attitudes.

The authors also use five references in the form of previous journals that have themes that are in line with the research. Journals that are used as references are: Pengaruh Kredibilitas Influencer Terhadap Sikap Pada Merek (Studi pada Mahasiswa Fakultas Komunikasi dan Bisnis Universitas Telkom) (Sugiharto \& Ramadhana, 2018), Pengaruh Endorser Ulama Terhadap Sikap Dan Minat Beli Konsumen (Muthohar \& Triatmaja, 2013), Pengaruh Daya Tarik Iklan, Kreativitas Iklan dan Kredibilitas Endorser Terhadap Efektivitas Iklan dan Sikap Konsumen Pada Sabun Pemutih Wajah Merek Oil Of Olay Di Kota Pekanbaru (Legasari, Indarti \& Restuti, 2013), Analisis Perbandingan Pengaruh Endorser Terhadap Sikap Pada Merek Shampo Sunsilk dan Shampo Pantene (Rosi \& Andjarwati, 2018), and, Analisa Credibility Celebrity Endorser Model: Sikap Audience Terhadap Iklan dan Merek Serta Pengaruhnya Pada Minat Beli "Top Coffee" (Soesatyo \& Rumambi, 2013).

The similarity of this study with the five previous studies is to both find out about the effect of promotional activities that collaborate with celebrity endorsers on brand attitudes. While the differences are the authors use the theory of celebrity endorser characteristics from Percy \& Rossiter which consists of visibility, credibility, attraction, and power to measure the influence of celebrity endorsers from various sides so that the information obtained is more concrete. Another difference in this study from previous research is that this study focuses only on one $x$ variable (celebrity endorser characteristics) and one $y$ variable (attitude towards brands).

This study is worthwhile to provide insight to marketers about promotional activities using celebrity endorsers and attitudes towards brands.

Based on the background of the problems described above, the formulation of research problems are: I. How is the response of active students of Communication Studies at Bakrie University regarding the characteristics of celebrity endorser Titan Tyra in the \#JajanAsikdiXXI campaign?; 2. How is the attitude of active students of Bakrie University Communication Science towards the XXI brand in the \#JajanAsikdiXXI campaign?; 3. Is there any influence of the characteristics of celebrity endorser "Titan Tyra" in the \#JajanAsikdiXXI campaign on the attitudes of active students of Communication Science at Bakrie University on the XXI brand?

The study measures student responses regarding the characteristics of celebrity endorsers Titan Tyra, by: I) measuring students' attitude toward the XXI brand, and 2) measuring the influence of the characteristics of celebrity endorser Titan Tyra in the \#JajanAsikdiXXI campaign on students' attitude toward the XXI brand.

\section{METHOD}

This research uses a quantitative approach through primary data obtained from the results of a questionnaire survey which is supported by secondary data from observations, search for professional documents, and digital documentation. between variable $X$ (celebrity endorser) to variable $Y$ (attitude towards brands) through data or samples that have been collected. This explanatory case study method is also considered appropriate because the authors use several data collection techniques. 
In this research, the population is active students of Bakrie University Communication Studies, with the criteria aged 19-25 years, urban, knowing Titan Tyra and familiar with the XXI brand.

Based on the results of the pre-survey of 40 active students of Communication Science at Bakrie University who were randomly selected, it was found that $67.5 \%$ of the respondents met the criteria needed by the authors to become the study population. So the authors assume that active students of Bakrie University Communication Studies who meet the criteria mentioned above are 614.25 rounded to 615 people (67.5\% of the total population: 910$)$.

The population in this research amounted to 615 people and the precision was set at $10 \%$, so the number of samples in this study was 86.0 I rounded up to 86 students.

The probability sample method the authors choose is cluster random sampling. Cluster random sampling is a technique of determining and selecting samples from small groups of units by lotion. These small units are considered to be representative of the existing population. The clusters used are classes from each course that takes place in the even semester of 2019/2020.

After knowing the number of samples needed, the authors divide the population based on the classes of each course that took place in the even semester 2019/2020. In this sampling process, the authors divide into two stages. First, the authors conduct drawing based on the course using a random generator. In the second stage, the authors draw the class code from the course chosen by the same drawing technique as the first stage.

From the drawing process the authors get 6 classes, they are Teori Komunikasi with code KOM2I I, Politik Ekonomi Media Massa with code KOM62, Riset Komunikasi Merek with code KOM62, Komunikasi Bisnis with code KOM42, Riset Komunikasi Massa with code KOM6I, and Perencanaan Strategi Media with KOM6I.
The next step is to contact the respondents based on the names on the selected class attendance list. The authors use Instagram's direct messages to contact respondents. Before distributing the questionnaire, the authors first screened the respondents through a screening question to adjust them to the characteristics of the population.

Methods of data collection that the authors use are described below.

\section{Distribution of Survey Questionnaires}

Sugiyono (2010) states that the questionnaire is a data collection technique that is carried out by providing a list of questions about research problems that must be answered by respondents. In this study, the questionnaires were distributed online with the Google form assistance.

\section{Observation}

Observational data collection was carried out to compare data from the questionnaire results and the actual situation. The authors use a combination of direct observation in the field and indirect observation via social media. This step is taken to make the authors get a broad and in-depth understanding of the XXI brand and the intended consumers.

Direct observation in the field was carried out through participant observation where the authors were part of the team that ran the \#JajanAsikDiXXI campaign on Instagram. From this participant observation, the authors can know the XXI brand's point of view. Indirect observation via social media is carried out to get another view from the consumer's point of view.

Media, Professional, and Scientific Document Search The authors conduct theoretical studies and references related to the problems being researched to get concrete answers to the existing problems. To support this research, the 
authors also collect data through media and professional document searches.

Data collection using scientific literature is carried out by examining library materials related to the problem understudies, such as books and journals. The use of media documents is done by browsing articles related to research problems and published in the media. Professional data is also needed as evidence that what is written is not just an assumption. The collected data will then be used as the basis for arguments and references in carrying out this research.

\section{Digital Documentation}

The technique of collecting documentation data is the collection of data in the form of images, works, and writings that have not been made by someone. The authors are documenting data by screenshoting or capturing photos as well as downloading videos and writings posted on digital platforms related to the \#JajanAsikDiXXI campaign and the XXI brand as a whole. The function of using this method is to documenting the historical data or digital traces where most of the data available are in the form of writing (statuses), videos, pictures, and so on that can support research.

The main data collection technique performed by distributing questionnaires to selected respondents. The questionnaires distributed by the authors are made in google form format and use a Guttman scale (ratio) to measure cognitive aspects and for other aspects using a differential semantic scale (interval).

The use of these two scales is carried out to measure the dimensions appropriately and in context. This is because the cognitive aspects cannot be measured using a semantic differential scale because for the knowledge aspect there must be a definite answer.

Validity is a measure that shows the levels of validity or validity of an instrument. An instrument that is valid or valid has high validity. On the other hand, less valid instruments have low validity (Arikunto, 20II).
The authors tested the validity of the questionnaire that had been filled in by 86 respondents to show the validity levels of a research instrument. With 86 respondents, and $10 \%$ alpha, the value of the $r$ table is 0.1786 . The value of $r$ table $=0.1786(d f=n-2=84, \alpha=$ $10 \%)$.

Each research question show a number greater than the value of $r$ table is $(0.1786)$ which means, the instrument that the authors use is considered valid and trustworthy

The authors also tested the reliability of the questionnaires. Reliability is an index that shows that an instrument cannot be trusted or reliable (Sugiyono, 20I0). Quoted from Sekaran (2017), the data are reliable if the Cronbach Alpha value is more than 0,6 . This is the result of the Reliability test:

Table I. The result of the $R$ test for $X$ Variable

\begin{tabular}{|c|c|}
\hline \multicolumn{2}{|c|}{ Reliability Statistics } \\
\hline Cronbach's Alpha & $\mathbf{N}$ of Items \\
\hline 0.943 & 21 \\
\hline
\end{tabular}

The results of the reliability test for the $X$ variable from 86 respondents showed Cronbach's equal to 0.943 . That means that these data are reliable.

Table 2. The result of the $R$ test for $Y$ Variable

\begin{tabular}{r|r}
\hline \multicolumn{3}{|c}{ Reliability Statistics } \\
\hline Cronbach's Alpha & N of Items \\
\hline .766 & 11 \\
\hline
\end{tabular}

The results of the reliability test for the $Y$ variable from 86 respondents showed Cronbach's Alpha value of 0.766 . That means that these data we are reliable. 
Table 3. The result of the $R$ test

Model Summaryb

\begin{tabular}{r|r|r|r|r}
\hline Model & $\mathbf{R}$ & R Square & Adjusted R Square & Std. Error of the Estimate \\
\hline 1 & $.73 \mathrm{la}$ & .535 & .529 & 9.446 \\
\hline
\end{tabular}

a. Predictors: (Constant), Celebrity endorser characteristics

b. Dependent Variable: Attitude toward brand

Source: SPSS Output Based on Primary Data

\section{FINDINGS AND DISCUSSION}

In this finding and discussion, the authors describe the influence of the characteristics of celebrity endorser Titan Tyra in the \# ajanAsikdiXXI campaign via Instagram on the attitudes of Bakrie University Communication Science students towards the $X X I$ brand. From the results of the collected respondent's answers, the authors then conducted a simple linear regression analysis and conducted hypothesis testing.

From the results of the questionnaire, it was found that student responses to the characteristics of celebrity endorser Titan Tyra were positive. it can be seen from the answers that are dominated by agreed responses on each dimension (visibility, credibility, attraction, and power). However, the response is still not very good for aspects of the similarity of celebrity endorsers with audiences and emotional attachment between celebrity endorsers and audiences.
The results of measuring student attitudes towards the $X X I$ brand in the \#JajanAsikdiXXI campaign have been dominated by positive responses for the cognitive and affective dimensions. The attitude shown is temporary, depending on the innovation and promotional activities carried out by XXI.

To determine the effect between the two variables, the authors conducted a simple regression test.

The $\mathrm{R}$ test aims to determine and measure how much influence between variables $X$ and Variable $Y$. This is the result of the $R$ Test:

The table above explains the magnitude of the correlation value $(R)$, which is equal to $0.73 \mathrm{I}$. This figure shows that the relationship that occurs between variable $X$ and variable $Y$ in this study is strong.

From the output, the coefficient of determination ( $R$ Square) is 0.535 , which implies that the simultaneous influence of the independent variable (Characteristics of

Table 4. The result of the $R$ test

\begin{tabular}{|c|c|c|c|c|c|c|}
\hline \multicolumn{7}{|c|}{ Coefficients $^{a}$} \\
\hline & \multirow{2}{*}{ Model } & \multicolumn{2}{|c|}{ Unstandardized Coefficients } & \multirow{2}{*}{$\begin{array}{r}\text { Standardized Coefficients } \\
\text { Beta }\end{array}$} & \multirow{2}{*}{$\mathbf{t}$} & \multirow{2}{*}{ Sig. } \\
\hline & & $\boldsymbol{\beta}$ & Std. Error & & & \\
\hline \multirow[b]{2}{*}{$\mathbf{I}$} & (Constant) & $.07 !$ & 6.592 & & .011 & .991 \\
\hline & $\begin{array}{l}\text { Characteristics of } \\
\text { Celebrity endorser }\end{array}$ & .568 & .058 & .731 & 9.828 & .000 \\
\hline
\end{tabular}

a. Dependent Variable: Attitude toward brand

Source: SPSS Output Based on Primary Data 
Celebrity Endorser) on the dependent variable (attitude towards brands) is $53.5 \%$. The remaining $46.5 \%$ is influenced by other factors not examined here.

The test results show a constant value $(\alpha)$ of $0.07 \mathrm{I}$ while the Celebrity endorser Characteristic value ( $w /$ regression coefficient) is 0.568 so that the regression equation can be written:

$$
\begin{aligned}
& y=\alpha+\beta X \\
& y=0.071+0.568 X
\end{aligned}
$$

a (constant) of 0.07 I means that the constant value of the attitude variable for brands is 0.071 (if $x$ variable $=0$ ). The $X$ regression coefficient of 0.568 states that every I point addition of the Celebrity endorser Characteristics value, the attitude towards the brand increases by 0.568 . The regression coefficient is positive, so that means the value of the variable $X$ to $Y$ is directly proportional.

Based on the Coefficients table, the $t$ value is $9,828>\mathrm{t}$ table 1.6632 , so it can be concluded that $\mathrm{H}^{0}$ rejected and $\mathrm{H}^{\prime}$ is accepted. That means that there is an influence of the characteristics of celebrity endorser "Titan Tyra" on the attitudes of Bakrie University Communication Science students towards the XXI brand in the \#JajanAsikdiXXI campaign.

\section{Student's Perception about Boba Queen}

Rossiter and Percy in Kertamukti (2015) said that the characteristics possessed by Celebrity endorsers include Visibility, Credibility, Attraction, and Power (Vis-CAP model).

\section{Visibility}

The selection of endorsers is generally based on popularity and has a strong influence on society. This is needed so that the attention of potential consumers can be diverted to the brand being promoted. The higher one's visibility, the greater and wider the reach of the communication process being carried out.

Based on the answers to the questionnaire results in the visibility dimension, from the three statements obtained the dominant answer agrees. From the answers obtained, it is known that the majority of active Bakrie University Communication Science students know and pay attention to Titan Tyra. This also shows that active Bakrie University Communication Science students have positive responses and responses regarding the visibility of Titan Tyra.

Response Agree on the statement "I know the figure of Titan Tyra" has the highest percentage, namely $33.7 \%$ compared to the other two statements. Meanwhile, in the second position, the highest response was a very agreeable response to the statement "I know Titan Tyra is dubbed the Boba Queen" with a percentage of $32.6 \%$. From the two results of these statements, it can be concluded that the choice of using Titan Tyra as a celebrity endorser $X X I$ is right in the aspect of visibility because Titan Tyra has popularity so that it can attract the attention of the target consumers. Besides that, Titan Tyra's nickname as Boba Queen is also known by active students of Communication Science at Bakrie University. This will make it easier for XXI to achieve its goals.

\section{Credibility}

Endorsers must have the credibility to foster confidence and a level of trust from potential customers in the products they promote. Two factors affect the credibility of an endorser, namely expertise and trustworthiness.

Based on the answers to the questionnaire results in the credibility dimension, the dominant answers obtained agree on two statements and strongly agree on three statements. This shows that the majority of active Bakrie University Communication Science students have positive responses and responses regarding the credibility of Titan Tyra.

As mentioned earlier, Titan Tyra has the nickname Boba Queen. This nickname not only shows that Titan is someone who likes boba. Indirectly, the nickname Boba Queen created a 
quick association and has formed the perception that Titan is a person who is accustomed to consuming boba so that he has the expertise of taste and the reviews can be trusted. Apart from that, the respondents' trust and other expertise can value the content that Titan displays on social media.

Response Agree about the statement "Titan Tyra shows the real person on social media" had the highest percentage, namely $40.7 \%$ compared to the other four statements. Whereas in the second position the highest response was the response that strongly agreed with the statement "As a Boba Queen, Titan Tyra knows Boba XXI drinks" with a percentage of $39.5 \%$.

From these two statements, according to an active student of Communication Science at Bakrie University, Titan Tyra is someone who has credibility. This credibility arises from ratings about Titan showing his true personality on social media. The nickname Boba Queen also plays an important role in cultivating trust. From the results of the respondents' answers, it can be seen that Titan is considered capable of fulfilling two factors in the credibility dimension, namely expertise and trust. Titan Tyra's credibility makes messages and reviews about Boba $X X I$ well received by audiences.

\section{Attraction}

Endorsers are expected to have the charm that makes them different from others and makes the audience feel attached. Two characteristics form an attraction, namely likability (likeability) and similarity (similarity).

Based on the answers to the results of the questionnaire that the authors has described in the attraction dimension, the responses agree, strongly agree, and strongly agree that the numbers are almost equal. So it can be concluded that the majority of active Bakrie University Communication Science students strongly agree that Titan Tyra is a figure that has its charm. This result is by the persona Titan always shows through his Instagram and YouTube.
Responses Strongly agree on the statements "Titan Tyra has an attractive physical appearance" and "Tyra has a good style of dress" shared the highest percentage at $46.5 \%$ compared to the other six statements. This happens because Titan Tyra's content on social media is mostly focused on content about beauty and fashion style. Both statements are part of the likeability aspect.

The answers to the similarity aspect tend to be lower than the answers about the fascination. According to the authors's analysis, this happens because the persona Titan displays on social media is someone who is hedonistic and from the top. It can be seen from Titan's posts that often show branded goods and luxury holidays. This is not relatable to the respondents who are students.

\section{Power}

The position or size of the name is very important to support the strength of the endorser. The greater the power that is owned, the greater the influence in conveying the message.

Based on the answers to the results of the questionnaire that the authors has described in the power dimension, the most responses stated agree. So it can be concluded that the active students of Bakrie University Communication Science respond positively and agree that Titan Tyra has the power to influence them.

The agreed response regarding the statement "I am interested in looking for more detailed information about Boba XXI after seeing Titan Tyra's post" had the highest percentage, namely $32.6 \%$ compared to the other four statements. From this statement, it can be seen that Titan Tyra was able to influence respondents to seek more information about Boba XXI through its posts.

From the answers to each dimension obtained from the respondents, it can be concluded that the credibility dimension has the highest positive response. This is in line with previous research by Sugiharto \& Ramadhana 
(2018) who identified the influence of influencer credibility on brand attitude, stating that respondents see influencer credibility rather than influencer attractiveness.

\section{Student's Perception about XXI}

Schiffman \& Kanuk (2010) explained that attitude consists of three components, namely cognitive, affective, and conative. The authors discuss each component one by one.

\section{Cognitive}

Cognitive is the consumer's knowledge and perception of an object. Knowledge is obtained information that is scattered from various sources. Meanwhile, perception is formed from a person's experience with an object.

Based on the answers to the results of the questionnaire that the authors have described In the cognitive dimension, of the three existing statements, all of them were dominated by "yes" answers. This shows that almost all active students of Bakrie University Communication Science know the $X X I$ brand and the collaboration made by the XXI brand together with Titan Tyra in promoting Boba XXI.

The "Yes" response to the statement "I believe $X X I$ sells good quality Boba after seeing Titan Tyra's post" had the highest percentage at 93\% compared to the other two statements. It can be concluded that Titan Tyra has an important role to help shape perceptions about the quality of Boba XXI in the minds of active students of Communication Science at Bakrie University. Titan Tyra is someone who has credibility. This credibility arises from ratings about Titan showing his true personality on social media. The nickname Boba Queen also plays an important role in cultivating trust.

Also, the statement "I know XXI sells Boba products after seeing Titan Tyra's post" received a "Yes" response of $84.9 \%$. This means that Titan Tyra has succeeded in helping to spread awareness about XXl's newest product, Boba. From these results, it can be seen that the use of celebrity endorsers can target the appropriate target market more effectively. This is because every celebrity endorser has fans or followers with homogeneous characters and age aspects. After all, they are formed from people who have the same interests.

According to Kotler \& Gary (20I2), brand attitude is the attitude shown by consumers which are obtained from the results of evaluating a brand. Attitude toward brands is also a form of consumer expression in assessing the positive or negative of a brand. Do they like or dislike the products of the brand? Consumer attitudes are an important element that influences the success or failure of the marketing strategy undertaken (Lee \& Johnson, 20I I). The attitude toward brand describes how consumers act in a real way like making choices about a brand.

\section{Affective}

Affective refers to the emotions and feelings of consumers. According to Sciffman and Kanuk (2010), the affective component acts as primary evaluative in nature, which is an indication in the direct and general assessment of a product. The outcome of the assessment is whether the product is liked or not; or whether the product is good or bad.

Based on the answers to the results of the questionnaire that the authors have described in the affective dimension, it is known that the answers agree and strongly agree dominate each of the two statements. This shows the emotions and feelings of active Bakrie University Communication Science students towards the XXI brand and the collaboration made by the $X X I$ brand together with Titan Tyra. But what is interesting is that there is one statement that is dominated by disagreeing answers, namely the statement about emotional attachment. This shows that the respondents have positive feelings about the collaboration made by the XXI brand together with Titan Tyra, but they do not feel emotionally attached.

The statement in question is the statement "I have an emotional attachment to 
XXI after seeing Titan Tyra's post about Boba XXI" which is dominated by a "disagree" response with a percentage of $25.6 \%$. This shows that even though $X X I$ releases boba following the trend, $X X I$ has not been able to fulfill the respondents' preferences and build an emotional attachment to consumers.

From the results of the answers to the affective dimension statement, it can be concluded that active students of Bakrie University Communication Studies show positive responses and emotions to the \#JajanAsikdiXXI campaign. Titan Tyra is one of the added values for forming positive attitudes and emotions. However, the relationship between the brand XXI and the respondent and Titan Tyra's relationship with the respondent is not too deep so that it cannot make respondents feel emotionally attracted to them.

\section{Conative}

Conative refers to the act or behavior tendency towards an object. Conative relates to the action a consumer will take (likelihood or tendency) and is often called intention.

Based on the answers to the results of the questionnaire that the authors have described in the conative dimension, it shows that the answers agree and strongly agrees are the answers that most often appear. From these results, do something after seeing the collaboration done by the XXI brand together with Titan Tyra.

The "agree" response regarding the statement "I am looking for information about boba XXI independently after seeing Titan Tyra's post" has the highest percentage of $30.2 \%$ compared to the other two statements. This shows that active Bakrie University Communication Science students feel motivated and take action after seeing Titan Tyra's post. This is good because it means that the post from Titan has succeeded in triggering curiosity about the product being promoted.

Overall, the attitude of active Bakrie University Communication Science students towards the XXI brand tends to be good and positive. From the cumulative answers obtained from the respondents, it can be concluded that the cognitive dimension is the most affected aspect. Titan Tyra can be an informant who not only provides information but can also form positive perceptions

\section{How Boba Queen Affects Student's Attitude towards XXI Brand}

From the results of the $F$ test it is known that the value of Fcount $=96.595$ and Ftable $=2.77$ $(n 1=1, n 2=84)$, with a significance level of $0.000<0.05$. This means that the regression model can be used to predict the attitude variable on brands because it statistically shows that there is a simultaneous or simultaneous influence between the variable Celebrity Endorser Characteristics $(X)$ on the attitude variable on brands $(Y)$.

The research results on the simultaneous test provide a statement that in theory and reality in the field, information processing via the peripheral route can form a positive attitude among active students of Communication Science at Bakrie University. Previously, the authors had explained that the processing of information on the peripheral route, the receiver pays more attention to the supporting aspects in the form of communicator appeal, product packaging, or other visual aspects.

In this study, Titan Tyra became a communicator whose job was to convey persuasive messages to the receiver. The characteristic of Titan Tyra as a celebrity endorser is an attraction that can attract the attention of the audience. The attention of the audience is what will help change attitudes. The changes that occur due to persuasive messages in this peripheral route are temporary.

Titan Tyra fulfils the characteristics of celebrity endorsers put forward by Rossiter and Percy, namely having visibility, credibility, attractiveness, and strength. Based on the results of respondents' answers that have been previously described, it is known that the credibility characteristic has the most positive 
responses compared to the other three characteristics.

These results are consistent with previous research by Rosi and Andjarwati (2018) which comparatively analysing the effect of endorsers on attitudes in the brands of Sunsilk and Pantene shampoo. The results of this study indicate that endorsers influence the formation of positive attitudes. This research also produces the same statement that the aspects of credibility and endorser's expertise have a greater influence than attractiveness. This statement proves that consumers are critical in capturing messages. The attractiveness of communicators can indeed help the process of persuasive communication to be more effective, but this factor is not the single most determining factor.

Based on the results of the t-test conducted by the authors on the answers of the respondents, the $t$ value is $9,828>t$ table 1.6632 and sig $0.00<0,05$, so it can be concluded that it is rejected and accepted. This means that the characteristics of celebrity endorsers "Titan Tyra" have a positive and significant influence on the attitudes of Bakrie University Communication Science students on the XXI brand in the \#jajanAsikdiXXI campaign.

This is also in line with previous research by Muthohar \& Triatmaja (2013) who studied the influence of ulama endorsers on consumer purchase attitudes and interest. This study states that all endorser characteristics have a significant positive effect on attitudes. This proves that the characteristics of the endorser in promoting a product or brand have an important role in influencing attitudes. The more attractive the characteristics shown, the easier it is to form the desired attitude.

Based on the hypothesis test, the characteristics of celebrity endorsers which have four dimensions (visibility, credibility, attraction, and power) influence the attitude toward brand, so they are rejected. This shows that the characteristics of the celebrity endorser "Titan Tyra" affect the active students of
Communication Science at Bakrie University in their attitude towards the XXI brand.

In the analysis that has been described previously, it is proven that the variable characteristics of celebrity endorser "Titan Tyra" has an effect of $53.5 \%$ on attitudes towards brands, and the remaining $46.5 \%$ is influenced by other factors not examined in this study. These factors are formed from several possibilities that may occur outside of this research, such as price, advertising appeal, and promotional creativity.

When viewing the previous research by Legasari, Indarti, \& Restuti (2013) in the effect of advertising attraction, advertising creativity and endorser's credibility on advertising effectiveness and consumer attitudes on face whitening soap brand Oil of Olay in Pekanbaru city, we found that the attraction factor of the advertisement and advertising creativity also has a direct and significant effect on consumer attitudes. However, the factors that have been described above are still possible because the subject, object, and time of the study also affect the final result.

The results of this study are based on the data and analysis that has been done. After testing with the help of statistical software, it can be seen that the characteristics of celebrity endorser Titan Tyra have a positive and significant effect both on the attitude toward brand XXI studies on active students of Communication Science at Bakrie University. These results are following the intended hypothesis so that the hypothesis can be accepted.

Changes in attitudes that occur in active students of Communication Studies at Bakrie University in the \#jajanAsikdiXXI campaign started with the persuasive message experiment delivered by Titan Tyra. The message is then processed through the peripheral path, which in processing focuses more on the attractiveness of the communicator. The attraction referred to in this study is the characteristics of celebrity endorser Titan Tyra which includes, visibility, 
credibility, attraction, and power. After testing it is known that the celebrity endorser characteristics can influence brand attitudes by $53.5 \%$.

\section{CONCLUSION}

This study examines the effect of the characteristics of celebrity endorsers "Titan Tyra" in the \#jajanAsikdiXXI campaign via Instagram on the attitudes of Bakrie University Communication Science students towards the $\mathrm{XXI}$ brand. Based on the results of data analysis as described above, a conclusion can be drawn as follows.

First, the majority of active students of Bakrie University Communication Science gave ratings, responses, and positive responses to the characteristics of celebrity endorser Titan Tyra in the \# JajanAsikdiXXI campaign. The credibility factor is the characteristic that gets the most positive responses. Titan Tyra's nickname as Boba Queen helps respondents to believe the message that Titan conveyed in the \#jajanAsikdiXXI campaign on Instagram.

Second, the majority of active students of Bakrie University Communication Science gave positive scores to the brand attitude questionnaire $(\mathrm{Y})$. The $\mathrm{XXI}$ brand can create positive attitudes and foster respondents' interest in their latest products through the \#jajanAsikdiXXI campaign which collaborates with Titan Tyra on Instagram.

Third, there is an influence from the characteristics of celebrity endorser Titan Tyra on attitudes towards brand XXI. Based on the results of the simple linear regression test, the results of the regression coefficient of this study are positive, so it can be said that the value of the variable $X$ to $Y$ is directly proportional. All the characteristics of celebrity endorsers attached to Titan Tyra have a significant and simultaneous influence on the attitudes of active students of Communication Science at Bakrie University towards attitudes towards the $\mathrm{XXI}$ brand. The characteristics referred to include, among others, visibility, credibility, attractiveness, and power.

This study encountered problems in data collection so that the population and sample used were too small that they could not represent the students as a whole. Therefore, this study has some implications to be considered by brands and future studies.

\section{Theoretical Implications}

The authors suggest adding other variables outside the celebrity endorser characteristics in further research in order to get unlimited new insights. There are other factors that influence brand attitude. These factors are formed from several possibilities that may occur outside of this research, such as price, advertising appeal and promotional creativity. However, the factors that have been described above are still possible because the subject, object, and time of the study also have an effect on the final result. Therefore it is suggested that $x x i$ and further researchers be able to explore and find out other factors that can affect attitudes towards brands.

\section{Methodological Implications}

The authors expect this research could be a reference to other researchers to be developed in subsequent research that is consistent with the study. This study experienced problems in data collection so that the population and sample used were too little in the next research, so it should be able to use a wider sample and population so that the results obtained were able to represent students more widely and thoroughly.

\section{Practical Implications}

The characteristics of celebrity endorsers have a significant effect on brand attitudes. For this reason, XXI needs to maintain and choose wisely celebrity endorsers to work with. Because the effect is significant, there are still many things that need to be improved from this endorser, including increasing the aspects that 
are still low in this study such as the similarity of celebrity endorsers with the audience and emotional attachment between the celebrity endorser and the audience. Meanwhile, the aspects of credibility, visibility, and strength must be maintained.

The use of celebrity endorsers only makes temporary attitude changes. For this reason, if you want a long-term change in attitude, the authors propose to create a sustainable communication strategy. Besides, the use of celebrity endorsers has more influence on cognitive and affective aspects, while the conative aspects have a less significant impact.

\section{References}

Andani, F. (2019, January I6). Keluhan mengenai XXI [Complaint on XXI]. Twitter [Tweet on Twitter]

Arikunto, S. (201I). Prosedur Penelitian [Research Procedure]. Penerbit PT. Rineka Cipta

Cinema21. (2019, December 22). Postingan Menu Baru [New Menu Posts]. Instagram. [InstagramPost].

Cinema2I. (n.d.). Profile Cinema2I. 2I Cineplex.com. [Website]

Cravens, D.W. (20I3). Strategic Marketing. McGrawHill

Harsono, F. H. (2019, December 26). Popularitas Minuman Boba di Indonesia Melejit Selama 2019. Liputan6.com [OnlineMedia].

Hiip. (2020). Profile Influencer: Titan Tyra. Professional Document.

Kertamukti, R. (2015). Strategi Kreatif Dalam Periklanan: Konsep, Media, Branding, Anggaran [Creative strategy in advertising: concept, media, branding, budget]. Rajawali Pers

Kingsnorth, S. (2016). Digital marketing Strategy: An Integrated Approach to Online Marketing. Kogan Page

Kotler, P. \& Gary, A. (2012). Prinsip-prinsip Pemasaran [Principles of Marketing]. Erlangga.

Lee, M., \& Johnson, C. (20II). Prinsip-Prinsip Pokok Periklanan dalam Perspektif Global [Basic Principles of Advertising in Global Perspectives]. Prenada Media.

Legasari, V. E., Indarti, S. \& Restuti, S. (20/3). Pengaruh Daya Tarik Iklan, Kreativitas Iklan dan Kredibilitas Endorser Terhadap Efektivitas Iklan dan Sikap Konsumen Pada Sabun Pemutih Wajah Merek Oil of Olay di Kota Pekanbaru [The effect of advertising attractiveness, advertising creativity and endorser credibility on advertising effectiveness and consumer attitudes towards the Oil of Olay facial whitening soap brand in Pekanbaru city]. Jurnal Ekonomi, 2I(3), I-I5 [CrossRef].

Muthohar, M., \& Triatmaja, A. R. (20/3). Pengaruh Endorser Ulama Terhadap Sikap Dan Minat Beli Konsumen [The influence of ulama endorsers on consumers' attitudes and purchase interests]. Jurnal Bisnis dan Ekonomi JBE, 19(I), 86-99 [GoogleScholar].

Nursatyo \& Rosliani, D. (2018). Strategi Komunikasi Pemasaran Digital Situs Pembanding Harga Telunjuk.com [Digital marketing communication strategy of the price comparing site Telunjuk.com]. Expose: Jurnal Komunikasi, I (2), 4667 [CrossRef]

Purwana, D., Rahmi, R., \& Aditya, S. (2017). Pemanfaatan Digital marketing Bagi Usaha Mikro, Kecil, dan Menengah (UMKM) di Kelurahan Malaka Sari, Duren Sawit. Jurnal Pemberdayaan Masyarakat Madani, I(I), I-I7 [CrossRef].

Pughazhendi, A \& Ravindran, D.S. (20I2). A Study on the Influence of Using Celebrity Endorsements on Consumer Buying Behaviour in Tamil Nadu, India. Journal of Research in International Business Management, 2(4), 89-96 [GoogleScholar].

Rosi, F. \& Andjarwati, A. L. (2018). Analisis Perbandingan Pengaruh Endorser terhadap Sikap pada Merek Shampo Sunsilk dan Shampo Pantene [Comparative analysis of the endorser influence towards brand attitude of Sunsilk and Pantene shampoos]. BISMA (Bisnis dan Manajemen), 6(I), 32-40. [CrossRef].

Ryan, D. (20I5). Understanding Social Media How to Create a Plan for Your Business that Works. KoganPage

Schiffman, L. G., \& Kanuk, L. L. (2010). Consumer Behavior, 10th Edition. Pearson Education.

Sekaran, U. (2017). Metodologi Penelitian Untuk Bisnis [Research Methodology for Business]. Salemba Empat

Soesatyo, N., \& Rumambi, L. J. (20/3). Analisa Credibility Celebrity Endorser Model: Sikap Audience Terhadap Iklan dan Merek Serta Pengaruhnya Pada Minat Beli "Top Coffee" [Analysis of celebrity endorser credibility model: audience attitudes towards advertisements and 
brands and their influence on buying interest "Top Coffee"]. Jurnal Manajemen Pemasaran, I(2), I-I 2 [GoogleScholar].

Sugiharto, S. A., \& Ramadhana, M. R. (20|8). Pengaruh Kredibilitas Influencer Terhadap Sikap Pada Merek. Jurnal Ilmu Politik dan Komunikasi, 8(2) [GoogleScholar].

Sugiyono. (2010). Metode Penelitian Pendidikan: Pendekatan Kuantitatif, Kualitatif, dan R\&D [Education Research Method: Quantitative, Qualitative, and R\&D Approach]. Alfabeta

Totoatmojo, K. M. (20I3). The Celebrity endorser (Selebgram) Effect toward Purchase Intention on Instagram Social Media. 3rd AASIC, 7I-78 [GoogleScholar].

Tyra, T. (2019, Juny 17). Playlist Titan Boba Queen. Youtube [Video].

Tyra, T. (2020, January 29). Postingan Titan Tyra \#JajanAsikDiXXI. Instagram [InstagramPost].

Tyra, T. (2020). Youtube Titan Tyra. Youtube [Video].

Wijaya, B. S. (20I3). Dimensions of Brand Image: A Conceptual Review from the Perspective of Brand Communication. European Journal of Business and Management, 5(3I), 55-65 [GoogleScholar] [CrossRef].

XXI. (2020). Brief Next Campaign of Brown Sugar Milk Boba \#JajanAsikDiXXI. Professional Doc. 